\title{
Antibacterial Activity and Flavonoids Content of Artemisia cina Berg. ex Poljakov Ethyl Acetate Extracts
}

\author{
Sri Kasmiyati ${ }^{1}$, Elizabeth Betty Elok Kristiani ${ }^{*}$, Maria Marina Herawati ${ }^{2}$, Andreas Binar Aji \\ Sukmana ${ }^{1}$
}

\author{
${ }^{1}$ Faculty of Biology, Satya Wacana Christian University, Indonesia \\ ${ }^{2}$ Faculty of Agriculture and Business, Satya Wacana Christian University, Indonesia \\ *Corresponding Author: betty.elok@uksw.edu
}

Submitted: 2020-12-11. Revised: 2021-01-09. Accepted: 2021-03-20

\begin{abstract}
The medicinal plant-derived bioactive compounds have a potential for many biological activities, including antimicrobial activity. Artemisia cina is a medicinal plant from the Compositae family with the potential of having antitumor, antifungal, and antibacterial activity. This study aimed to determine the antibacterial activity and the flavonoid content of $A$. cina's ethyl acetate extract. Plants samples were extracted by ethyl acetate maceration method. Antibacterial activity was tested against Gram-negative bacteria (Escherichia coli and Pseudomonas aeruginosa) and Gram-positive bacteria (Bacillus subtilis and Staphylococcus aureus) by a disk diffusion method using 25, 50, and $100 \mathrm{mg} / \mathrm{l}$ extract concentrations. The flavonoid contents (quercetin and kaempferol) were measured using High-Performance Liquid Chromatography. The extracts of diploid and polyploid A. cina displayed some antibacterial activity, with the Gram-negative bacteria being more resistant than the Gram-positive counterpart. However, no significant difference was observed between the diploid and polyploid extracts. As for the flavonoid content, the highest quercetin content $(0.5501 \mathrm{mg} / \mathrm{ml}) \mathrm{was}$ found in the polyploid A. cina (J), while the highest kaempferol content $(0.5818 \mathrm{mg} / \mathrm{ml})$ was observed in the diploid $A$. cina (KJT). Although A. cina is widely grown in Indonesia, compared to other Artemisia species, A. cina has not been widely studied, especially its antibacterial potential and in related to its flavonoid content and the use of ethyl acetate as the extraction solvent. This study reveals the potential of $A$. cina as a natural antibacterial agent.
\end{abstract}

Key words: antibacterial; Artemisia cina; ethyl acetate; kaempferol; quercetin

How to Cite: Kasmiyati, S., Kristiani, E. B. E., Herawati, M. M., \& Sukmana, A. B. A. (2021). Antibacterial Activity and Flavonoids Content of Artemisia cina Berg. ex Poljakov Ethyl Acetate Extracts. Biosaintifika: Journal of Biology \& Biology Education, 13(1), 106112 .

DOI: http://dx.doi.org/10.15294/biosaintifika.v13i1.27665

\section{INTRODUCTION}

The extensive antibiotics use leads to an increased bacterial resistance. The uncontrolled use of antibiotics is tightly associated with adverse effects in humans (Massiha et al., 2013). The increasing incidence of bacterial resistance to certain antibiotics has caused problems in many infectious disease treatments. Therefore, it is crucial to explore new potential antibiotics. One of the promising sources of the new antibiotics is from medicinal plants. Some bioactive compounds isolated from medicinal plants have been used as antibiotic alternatives due to their antimicrobial activities. Thus, many medicinal plants received significant attention for the new antibiotic developments (Compean \& Ynalvez, 2014).

Many traditional medicinal plants are known to produce bioactive compounds such as phenolics, alkaloids, flavonoids, and terpenoids (Othman et al., 2019). Flavonoid compounds have been reported to contribute to antimicrobial activity. With the presence of other bioactive compounds, flavonoids showed different antibacterial activities (Mariita et al., 2011). Flavonoids inhibit bacteria by directly killing the bacteria, synergistically activating antibiotics, and attenuating bacterial pathogenicity. Thus, reducing the harm to the host organism (Xie et al., 2015). A large concentration of flavonoids can be found in the stem, leaves, flowers, and fruit of many species from Compositae family (Panche et al., 2016; Taleghani et al., 2020). Artemisia is one of the genera in the Compositae family which has the potential to be studied for its flavonoid content and antibacterial activity. Artemisia contains bioactive compounds such as essential oils, monoterpenes, flavonoids, sesquiterpenes lactone, $\alpha$-xanthine, and artemisinin acid, which contribute to its medicinal properties (Ahameethunisa \& Hopper, 2010). Those compounds were known to act as antibacterial agents (Tan et al. 1998). Several studies of antibacterial activity from various extracts of Artemisia species have been reported. Ahameethunisa and Hopper (2010) reported that the hexane extract of A. nilagirica leaves displayed an inhibition against various groups of bacteria.

The water fraction of $A$. indica showed maximum activity against Bacillus subtilis (Bibi et al., 2011). The methanol and ethanol extracts of $A$. annua leaves demonstrated an inhibition against Klebsiella 
pneumonia PTCC 1053, Shigella dysenteriae PTCC 1188, Salmonella enterica PTCC 1231, Escherichia coli PTCC 1399, and Staphylococcus aureus PTCC 1431 (Tajehmiri et al., 2014). The reported studies on antibacterial activity of Artemisia usually related to its essential oils. The essential oils content of various Artemisia species and their antibacterial activity that have been studied are A. herba-alba (Mohamed et al., 2010; Younsi et al., 2016), A. absinthium (Joshi, 2013; Msaada, et al., 2015), Artemisia spp. (Dadasoglu et al., 2015), A. апnиa (Massiha et al., 2013), A. arborescens (Militello, et al., 2011), A. nilagirica (Ahameethunisa \& Hopper, 2010), A. vulgaris (Addo-Mensah et al., 2015), and A. cina (Kristiani et al., 2015).

The other antibacterial potential of A. cina which is widely grown in Indonesia has not been studied, especially related to its flavonoid content and the use of ethyl acetate as the extraction solvent. The study of the potential antimicrobial activity of ethyl acetate extract of A. cina can provide meaningful information as an alternative for an antibacterial agent. Therefore, this study was conducted to determine the antibacterial activity and flavonoid content of A. cina ethyl acetate extract.

\section{METHODS}

\section{Plant material}

A. cina samples were obtained from B2P2TOOT (The Center for Research and Development of Medicinal Plants and Traditional Medicine), Tawangmangu, Central Java, Indonesia. The A. cina from $\mathrm{B} 2 \mathrm{P} 2 \mathrm{TO} 2 \mathrm{~T}$ which were propagated directly in the greenhouse and by tissue culture were diploid plant samples and were marked as TWN and KJT, respectively. Meanwhile, two samples of polyploid $A$. cina were created by polyploidization through the shoot culture technique. Genotype labeled $\mathrm{J}$ was created by $3 \mathrm{mg} / \mathrm{l}$ 2,4-D and $2 \mathrm{mg} / \mathrm{l} \mathrm{IBA}$ induction for 21 days. The $\mathrm{M}$ genotype was formed by $2 \mathrm{mg} / \mathrm{l} 2,4-$ $\mathrm{D}$ and $1.5 \mathrm{mg} / \mathrm{l} \mathrm{IBA}$ induction for 21 days.

\section{Plant extracts preparation}

All A. cina leaf samples were washed thoroughly using distilled water and were then air-dried without direct sun exposure. The dried leaves samples were finely ground using a blender (Philip HR1538). The powdered plant samples of as much as $50 \mathrm{~g}$ were extracted using the maceration method with ethyl acetate as a solvent and stirred using the magnetic stirrer for 3 hours. The maceration process was repeated five times for each sample. The extracts were then filtered (Whatman's filter paper), and the ethyl acetate filtrates were then concentrated using a rotary evaporator (Rotavapor R114 Buchi) under vacuum (Eyela A-1000S) at $40^{\circ} \mathrm{C}$. The extracts were dried at room temperature and were stored in the refrigerator until further analysis. The dried and powdered leaves (shoots) of $A$. cina were extracted by the maceration method using ethyl acetate as shown in Figure 1.

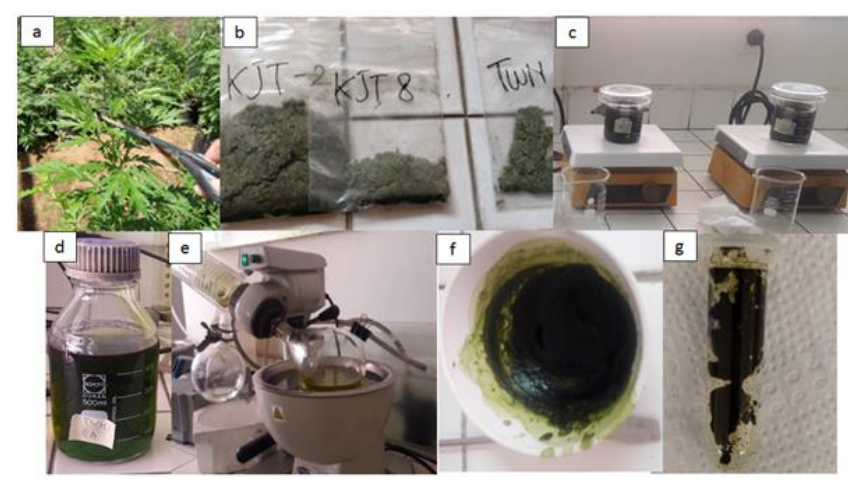

Figure 1. (a) A. cina plants, (b) dry powdered samples, (c) maceration process, (d) filtrate, (e) filtrate condensation using a rotary evaporator, (f) dried extract, and (g) collected extract for antibacterial analysis.

\section{Preparation of bacterial culture}

The bacteria used in this study were two species of gram-negative bacteria (Escherichia coli and Pseudomonas aeruginosa) and two gram-positive bacteria (Bacillus subtilis and Staphylococcus aureus). The bacteria were obtained from the culture collection InaCC, LIPI. The test bacteria were subcultured in Nutrient Agar (NA) medium and incubated overnight at $37^{\circ} \mathrm{C}$. Each isolate in the NA slope medium was taken with an inoculating loop and diluted with physiological saline solution. The turbidity of the bacterial suspension was adjusted to the density of $0.5 \mathrm{McF}$ arland standards, which equals to $1.5 \times 108 \mathrm{CFU} / \mathrm{ml}$ (Sutton, 2011; Yemata et al., 2019). The bacterial suspension was then taken as much as $100 \mu \mathrm{l}$ and evenly spread on previously prepared NA plates.

\section{Antibacterial activity test}

The antibacterial activity of the extracts was determined by the disk diffusion method (AddoMensah et al., 2015). The extracts of four genotypes of A. cina were dissolved in ethyl acetate as the solvent. Three extracts concentrations $(25,50,100$ $\mathrm{mg} / \mathrm{l})$ were tested against the four bacterial species. Each sterile paper disk (Oxoid) was placed on the previously seeded NA plates. During the application, the paper disks were pressed downward on NA plates. They were then infused with $20 \mu$ lof each tested extract and $100 \mu \mathrm{g} / \mathrm{ml}$ of Streptomycin as well as $100 \%$ ethyl acetate used as positive and negative controls, respectively. The seeded NA plates were 
incubated at $37^{\circ} \mathrm{C}$ for $24 \mathrm{~h}$, then the clear zone that was observed around the paper disk indicating the inhibition of bacterial growth. The complete inhibition zones around each of the disks were measured in mm using a ruler at the widest diameter including the disk for each of the NA plates.

\section{Flavonoid content determination}

The flavonoid content as kaempferol and quercetin was determined using High-Performance Liquid Chromatography (HPLC). The modification of Tokusoglu method (2003) was used to measured quercetin and kaempferol contents. The HPLC conditions for the separation of quercetin and kaempferol were using the Chromosorb Column RP C18 $(150 \times 5 \mathrm{~mm}$ id - Knauer $)$, H3PO4 0.1\%: acetonitrile (60:40) as the mobile phase, the flow rate $1 \mathrm{ml} / \mathrm{min}$, the volume of injection of $20 \mu \mathrm{l}$, ambient temperature, and using UV $370 \mathrm{~nm}$ detector. The quantitation of the amounts of the quercetin and kaempferol in A. cina sample extracts was determined using a calibration standard curve of quercetin and kaempferol pure compounds.

\section{Data analysis}

The data were analyzed using one-way analysis of variance (ANOVA) using the SAS ver. 9.1.3, followed by Tukey test to compare the mean difference between samples $(\mathrm{P}>0.05)$. All experiments were conducted in triplicate.

\section{RESULTS AND DISCUSSION}

\section{Antibacterial activity}

A. cina is one of the members of the genus Artemisia which is often used for medicinal purposes. In this study, the antibacterial activity potential of $A$. cina was determined by observing the growth inhibition zone on four bacteria species. Those bacteria including both Gram-positive (Bacillus subtilis and Staphyllococcus aereus) and Gramnegative (Escherichia coli and Pseudomonas aeruginosa). The clear zones formation in the disk diffusion method indicated an inhibition on bacterial growth due to the antibacterial activity (Figure 2). The antibacterial activity of $A$. cina ethyl acetate extract was compared to the standard antibiotic (streptomycin). The tested bacteria are widely used in antibacterial tests because these species are known to infect humans (Ahameethunisa \& Hopper, 2010).

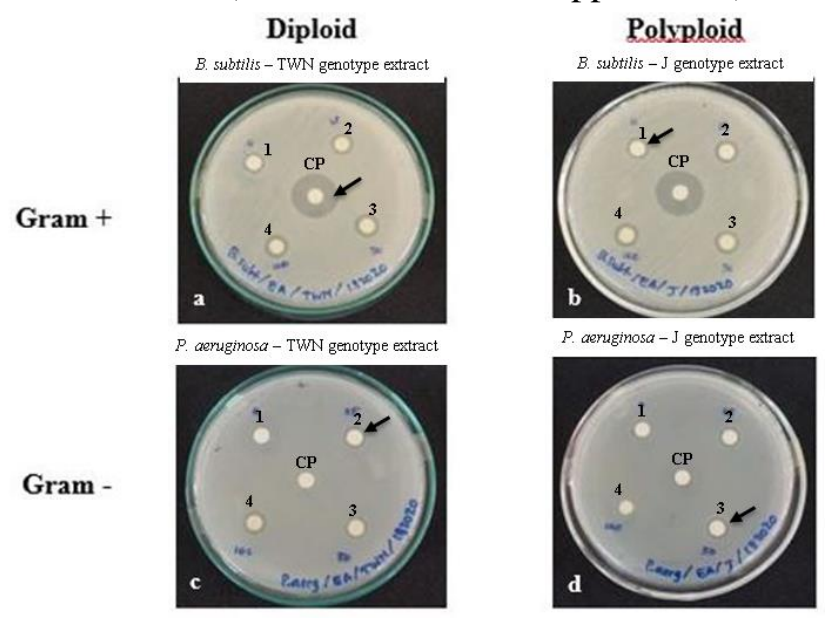

Figure 2. The antibacterial activity of $A$. cina ethyl acetate extracts tested using disk diffusion assay. The inhibition zone diameter (arrow) of the A. cina genotype represented here; (a) diploid TWN extract against Gram-positive $B$. subtilis, (b) polyploid $\mathrm{J}$ extract against Gram-positive B. subtilis, (c) diploid TWN extract against Gram-negative $P$. aeruginosa, and (d) polyploid $\mathbf{J}$ extract against Gram-negative bacteria $P$. aeruginosa. The four different extract concentrations used were 1. $0 \mu \mathrm{g} / \mathrm{ml}$ (negative control, a paper disk with solvent), 2. $25 \mu \mathrm{g} / \mathrm{ml}, 3.50$ $\mu \mathrm{g} / \mathrm{ml}$, and 4. $100 \mu \mathrm{g} / \mathrm{ml}$. The center paper disks (CP) with no label contain positive control streptomycin at $100 \mu \mathrm{g} / \mathrm{ml}$.

The result of the antibacterial activity of diploid and polyploid extracts against Gram-positive bacteria are shown in Table 1 dan Table 2. It can be observed that ethyl acetate extract of $A$. cina exhibited a slight inhibition on all tested bacteria (Figure 2, Table 1 and $2)$. The results showed that the extracts successfully inhibited the growth of $B$. subtilis and $S$. aureus. Also, the inhibitions were still lower compared to streptomycin. However, any significant inhibition was not observed among all tested extracts on a particular bacterium.

The polyploid mutants' ( $\mathrm{J}$ and $\mathrm{M}$ ) activity was not significantly different from the diploid genotype (KJT and TWN). The highest activity of $A$. cina extracts against $B$. subtilis was found at $50 \mathrm{~m} / 1$ for all tested genotypes. Overall, TWN and M genotypes showed a greater inhibition than KJT and J against the two Gram-positive bacteria, especially B. subtilis. 
Table 3 and Table 4 displayed the inhibition activity of the extracts against Gram-negative bacteria (E. coli and $P$. aeruginosa). Similarly, as previously demonstrated on Gram-positive, all four extracts' antibacterial activity against Gram-negative bacteria did not show significant differences between the genotypes. From the relatively small inhibition zone being displayed, it indicated that both $E$. coli and $P$. aeruginosa were more resistant against the extracts. The inhibition zones observed on the Gram-negative test plates were generally smaller compared to that of the Gram-positive. The susceptibility of bacteria to antibiotics is influenced by many factors, including phenotype and genotype variations in exposed bacterial populations. Bacterial resistance can develop either through the unexpressed expression of the previous resistant phenotype or as the result of an adaptation (Othman et al., 2019).

Previous studies also showed a similar pattern, the Gram-positive were more sensitive against the ethanol extract of A. cina than the Gram-negative bacteria. The essential oils from various Artemisia species exhibited a higher antibacterial activity on Gram-positive than on Gram-negative bacteria, such as A. апnua (Massiha et al, 2013), A. arborescens (Militello et al, 2011), A. cina (Kristiani et al., 2015), A. absinthium, and A. vulgaris (Poiata et al., 2009). Al-Wahaibi et al. (2020) reported that essential oils from two species of A. judaica and A. herba-alba had high antimicrobial activity against all test microorganisms, except for Gram-negative bacteria $P$. aeruginosa. The results of research conducted by Prastiyanto et al. (2020) report that extract of bilimbi (Averrhoa bilimbi) fruit with various solvents (methanol, ethanol, chloroform, n-hexane, and water) showed inhibition of growth to multi-drug resistance (MDR) bacteria. The extracts from the various solvents showed highly varying MBC (Minimum bactericidal concentration) values against MDR bacteria, but the lowest MBC value was found to water extract $(12.5 \mathrm{mg} / \mathrm{mL})$ against $\mathrm{ES} \beta \mathrm{L}+\mathrm{CR} P$. aeruginosa. Wahyuni et al. (2018) reported that the ethyl acetate extraction yield of Daemonorops draco was higher than methanol and n-hexane, and the ethyl acetate and methanol extracts showed stronger antimicrobial activity against $S$. aureus compared to n-hexane extract.

Table 1. The antibacterial activity of the A. cina diploid (KJT and TWN) and polyploid (M and J) genotype extracts against gram-positive bacteria Bacillus subtilis

\begin{tabular}{ccccc}
\hline \multirow{2}{*}{$\begin{array}{c}\text { Ethyl acetate extract } \\
\text { concentration }(\mathrm{mg} / \mathrm{l})\end{array}$} & Diploid $(\mathrm{KJT})$ & Diploid $(\mathrm{TWN})$ & Polyploid $(\mathrm{M})$ & Polyploid $(\mathrm{J})$ \\
\cline { 2 - 5 } & $8.17 \pm 1.04 \mathrm{cde}$ & $7.33 \pm 0.58 \mathrm{e}$ & $7.83 \pm 0.29 \mathrm{de}$ & $7.83 \pm 0.58 \mathrm{de}$ \\
25 & $9.33 \pm 0.58 \mathrm{~cd}$ & $8.67 \pm 0.58 \mathrm{cde}$ & $8.83 \pm 0.76 \mathrm{cde}$ & $8.67 \pm 1.15 \mathrm{cde}$ \\
50 & $9.50 \pm 0.50 \mathrm{~cd}$ & $9.67 \pm 1.15 \mathrm{c}$ & $9.67 \pm 0.58 \mathrm{c}$ & $9.33 \pm 1.15 \mathrm{~cd}$ \\
100 & $8.83 \pm 1.04 \mathrm{cde}$ & $9.33 \pm 1.15 \mathrm{~cd}$ & $8.50 \pm 0.50 \mathrm{cde}$ & $8.83 \pm 1.04 \mathrm{cde}$ \\
Streptomycin & $19.67 \pm 0.58 \mathrm{a}$ & $16.67 \pm 0.58 \mathrm{~b}$ & $18.00 \pm 2.00 \mathrm{~b}$ & $18.00 \pm 0.50 \mathrm{~b}$ \\
\hline
\end{tabular}

Results are the mean \pm standard deviation (SD) of three replications. Mean values in the same column and row with different letters are significantly different $(\mathrm{p}>0.05)$.

Table 2. The antibacterial activity of the A. cina diploid (KJT and TWN) and polyploid (M and J) genotype extracts against Gram-positive bacteria Staphyllococcus aureus

\begin{tabular}{ccccc}
\hline \multirow{2}{*}{$\begin{array}{c}\text { Ethyl acetate extract } \\
\text { concentration }(\mathrm{mg} / \mathrm{l})\end{array}$} & \multicolumn{4}{c}{ Diameter zone of inhibition (mm) } \\
\cline { 2 - 5 } & Diploid (KJT) & Diploid (TWN) & Polyploid (M) & Polyploid (J) \\
\hline 0 & $7.83 \pm 0.29 \mathrm{~b}$ & $7.00 \pm 1.00 \mathrm{bc}$ & $7.33 \pm 0.58 \mathrm{bc}$ & $5.00 \pm 0.29 \mathrm{c}$ \\
50 & $8.67 \pm 1.15 \mathrm{~b}$ & $7.67 \pm 0.58 \mathrm{~b}$ & $8.50 \pm 0.87 \mathrm{~b}$ & $7.67 \pm 0.58 \mathrm{~b}$ \\
100 & $7.83 \pm 0.29 \mathrm{~b}$ & $7.67 \pm 2.08 \mathrm{~b}$ & $8.83 \pm 0.76 \mathrm{~b}$ & $8.00 \pm 1.00 \mathrm{~b}$ \\
Streptomycin & $8.50 \pm 0.50 \mathrm{~b}$ & $7.67 \pm 0.58 \mathrm{~b}$ & $8.50 \pm 0.50 \mathrm{~b}$ & $8.00 \pm 1.73 \mathrm{~b}$ \\
\hline
\end{tabular}

Results are the mean \pm standard deviation (SD) of three replications. Mean values in the same column and row with different letters are significantly different $(\mathrm{p}>0.05)$. 
Table 3. The antibacterial activity of the A. cina diploid (KJT and TWN) and polyploid (M and J) genotype extracts against Gram-negative bacteria Escherichia coli

\begin{tabular}{ccccc}
\hline Ethyl acetate extract & \multicolumn{4}{c}{ Diameter zone of inhibition (mm) } \\
\cline { 2 - 5 } concentration $(\mathrm{mg} / \mathrm{l})$ & Diploid (KJT) & Diploid (TWN) & Polyploid (M) & Polyploid (J) \\
\hline 0 & $8.00 \pm 0.00 \mathrm{c}$ & $7.17 \pm 0.29 \mathrm{c}$ & $7.17 \pm 0.29 \mathrm{c}$ & $8.00 \pm 0.00 \mathrm{c}$ \\
25 & $8.17 \pm 0.29 \mathrm{c}$ & $7.33 \pm 0.76 \mathrm{c}$ & $8.17 \pm 0.29 \mathrm{c}$ & $8.00 \pm 0.00 \mathrm{c}$ \\
50 & $8.17 \pm 1.04 \mathrm{c}$ & $7.00 \pm 0.87 \mathrm{c}$ & $8.33 \pm 0.58 \mathrm{c}$ & $8.00 \pm 0.00 \mathrm{c}$ \\
100 & $7.67 \pm 0.76 \mathrm{c}$ & $8.17 \pm 0.76 \mathrm{c}$ & $7.67 \pm 1.15 \mathrm{c}$ & $8.00 \pm 0.00 \mathrm{c}$ \\
Streptomycin & $14.00 \pm 1.00 \mathrm{ab}$ & $13.33 \pm 0.58 \mathrm{~b}$ & $15.00 \pm 2.65 \mathrm{a}$ & $14.67 \pm 0.58 \mathrm{ab}$ \\
\hline
\end{tabular}

Results are the mean \pm standard deviation (SD) of three replications. Mean values in the same column and row with different letters are significantly different $(\mathrm{p}>0.05)$.

Table 4. The antibacterial activity of the A. cina diploid (KJT and TWN) and polyploid (M and J) genotype extracts against gram-negative bacteria Pseudomonas aeruginosa

\begin{tabular}{ccccc}
\hline \multirow{2}{*}{$\begin{array}{c}\text { Ethyl acetate extract } \\
\text { concentration }(\mathrm{mg} / \mathrm{l})\end{array}$} & \multicolumn{4}{c}{ Diameter zone of inhibition (mm) } \\
\cline { 2 - 5 } & Diploid (KJT) & Diploid (TWN) & Polyploid (M) & Polyploid (J) \\
\hline 0 & $6.67 \pm 0.29 \mathrm{abc}$ & $8.00 \pm 0.00 \mathrm{abc}$ & $7.83 \pm 1.26 \mathrm{abc}$ & $7.00 \pm 0.00 \mathrm{abc}$ \\
50 & $7.00 \pm 0.00 \mathrm{abc}$ & $8.00 \pm 1.00 \mathrm{abc}$ & $8.67 \pm 0.58 \mathrm{ab}$ & $8.00 \pm 0.00 \mathrm{abc}$ \\
50 & $5.33 \pm 0.29 \mathrm{c}$ & $8.33 \pm 0.58 \mathrm{abc}$ & $5.67 \pm 0.50 \mathrm{bc}$ & $8.33 \pm 0.58 \mathrm{abc}$ \\
100 & $8.33 \pm 0.58 \mathrm{abc}$ & $9.00 \pm 0.00 \mathrm{a}$ & $8.17 \pm 1.44 \mathrm{abc}$ & $7.00 \pm 1.00 \mathrm{abc}$ \\
Streptomycin & $6.50 \pm 0.00 \mathrm{abc}$ & $8.33 \pm 0.58 \mathrm{abc}$ & $6.50 \pm 0.00 \mathrm{abc}$ & $7.67 \pm 0.58 \mathrm{abc}$ \\
\hline
\end{tabular}

Results are the mean \pm standard deviation (SD) of three replications. Mean values in the same column and row with different letters are significantly different $(\mathrm{p}>0.05)$.

The Gram-positive bacteria are more sensitive against many plant extracts compared to the Gramnegative bacteria. Gram-positive bacteria's sensitivity can be related to the cell envelope constituents. It comprises an outer peptidoglycan layer that is relatively ineffective as a permeability barrier. Meanwhile, Gram-negative bacteria have lipopolysaccharide as their outer membrane envelope. This structure is a more resistant and more effective impermeable barrier (Al-Wahaibi et al., 2020; Baba \& Malik, 2014).

\section{Flavonoid content}

The development of natural antibiotics generally comes from medicinal plants. The medicinal plants usually produce important secondary metabolites such as alkaloids, terpenoids, essential oils, and phenolics (Othman et al., 2019). The antibacterial properties of $A$. cina might be attributed to the flavonoid contents such as kaempferol and quercetin. Therefore, their concentrations in the ethyl acetate extracts were analyzed by the HPLC method. The measurement results of flavonoid contents are displayed in Figure 3A (quercetin content) and 3B (kaempferol content).

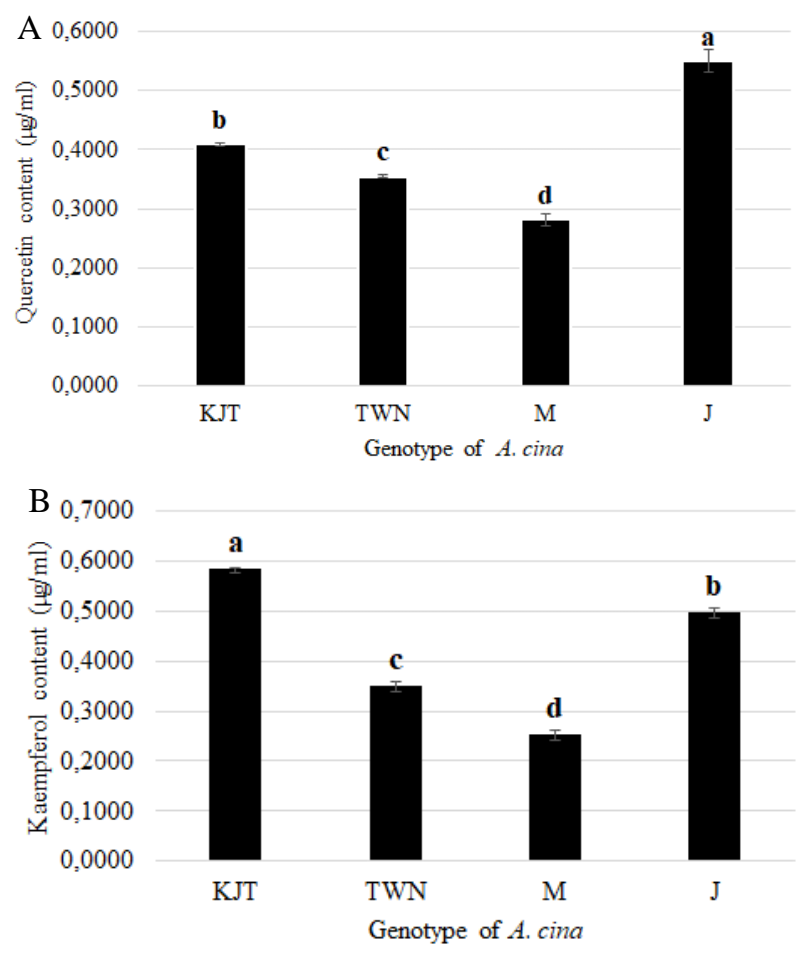

Figure 3. Quercetin (A) and kaempferol (B) contents of ethyl acetate extracts of diploid and polyploid $A$. cina plant. KJT and TWN genotype are the A. cina plant from B2P2TO2T which were propagated directly in the greenhouse and by tissue culture. M and $\mathrm{J}$ genotypes are A. cina were created by polyploidization through shoot culture technique. 
The flavonoid content of both quercetin and kaempferol showed a significant difference between the ethyl acetate extract of the genotype A. cina polyploid and diploid. The highest quercetin content at $0.5501 \mathrm{mg} / \mathrm{ml}$ was found in the genotype A. cina polyploid (J), while the highest kaempferol content was in the diploid genotype (KJT) at $0.5818 \mathrm{mg} \mathrm{ml}$. The lowest quercetin and kaempferol content were found in the polyploid (M) genotype. The high content of flavonoids in A. cina extracts was thought to be closely correlated with the higher and more effective antibacterial activity (Xie et al., 2015). Several flavonoid compounds exhibit antimicrobial actions such as quercetin, apigenin, myricetin, robinetin, luteolin. Quercetin exhibits antibacterial action by blocking ATPase activity in bacteria through protein binding (Othman et al., 2019; Shin et al., 2018). Many plant extracts with high flavonoid and terpenes content were reported to exhibit antibacterial activity, such as Zapoteca portorincensis (Agbafor et al., 2011), Ocimum gratissimum (Munyendo et al., 2011) Morinda citrifolia (Sibi et al., 2012), Phoenix dactylifera (Selim et al., 2012).

Studies on the use of Artemisia as a source of natural ingredients for the treatment of various diseases have been reported, including as an antimicrobial. The various species of Artemisia have been investigated for their antimicrobial activity. However, there is not much information about the the biological activity and secondary metabolite content of polyploid Artemisia, particularly A. cina. The results of this study are expected to provide new information, especially regarding the antibacterial activity and flavonoid content of $A$. cina polyploid, as well as adding information about Artemisia. Apart from that, it can also support the utilization of A. cina polyploid as a natural antibacterial source.

\section{CONCLUSION}

The ethyl acetate extract of $A$. cina from both diploid and polyploid genotype showed inhibition against the tested Gram-positive bacteria. A. cina extracts from all tested genotypes inhibit $B$. subtilis the most at a concentration of $50 \mathrm{mg} / \mathrm{l}$. A greater antibacterial activity was demonstrated by the diploid TWN and polyploid M genotypes against the Grampositive $B$. subtilis. The highest quercetin content $(0.5501 \mathrm{mg} / \mathrm{ml})$ was found in the polyploid $\mathrm{J}$ genotype, while the highest kaempferol content $(0.5818 \mathrm{mg} / \mathrm{ml})$ was in the diploid KJT genotype. The lowest quercetin and kaempferol content were found in the polyploid (M) genotype.

\section{ACKNOWLEDGMENT}

This research and publication are funded through the 2020 Desentralisasi Program under the Penelitian Dasar Unggulan Perguruan Tinggi (PDUPT) Scheme by the Ministry of Research and Technology/National Research and Innovation Agency of Republic Indonesia. The authors are greatly thankful for the funder.

\section{REFERENCES}

Addo-Mensah A., Garcia, G., Maldonado, I.A., Anaya, E., Cadena, G., \& Lee, L.G. (2015). Evaluation of antibacterial activity of Artemisia vulgaris extracts. Res. J. Med. Plant, 9, 234-240.

Agbafor, K.N., Akubugwo, E.I., Ogbashi, M.E., Ajah, P.M., \& Ukwandu, C.C. (2011). Chemical and antimicrobial properties of leaf extracts of Zapoteca portoricensis. Res. J. Med. Plant, 5, 605-612.

Ahameethunisa, A.R. \& Hopper, W. (2010). Antibacterial activity of Artemisia nilagirica leaf extracts against clinical and phytopathogenic bacteria. BMC Complementary and Alternative Medicine, 10(6), 1-6.

Al-Wahaibi, L.H.N., Mahmood, A., Khan, M., \& Alkhathlan, H.Z. (2020). Comparative study on the essential oils of Artemisia judaica and A. herba-alba from Saudi Arabia. Arabian Journal of Chemistry, 13, 2053-2065.

Baba, S.A. \& Malik, S.A. (2014). Evaluation of antioxidant and antibacterial activity of methanolic extracts of Gentiana kurroo Royle Saudi. J. Biol. Sci, 21, 493-498.

Bibi, Y., Nisa, S., Chaudhary, F.M., \& Zia, M. (2011). Antibacterial activity of some selected medicinal plants of Pakistan. BMC Complementary and Alternative Medicine, 11 (52), 1-7.

Compean, K.L. \& Ynalvez, R.A. (2014). Antimicrobial activity of plant secondary metabolites: a review. Research Journal of Medicinal Plant, 8(5), 204-213.

Dadasoglu, F., Kotan, R., Cakir, A., Cakmakei, R., Kordali, S., Ozer, H., Karagoz, K., \& Dikbas N. (2015). Antibacterial activities of essential oils extracts and some of their major components of Artemisia spp. L. against seed-borne plant pathogenic bacteria. Fresenius Environmental Bulletin, 24, 2715-2724.

Joshi, R.K. (2013). Artemisia capillaris: medicinal uses and future source for commercial uses from Western Himalaya of Uttrakhand. Asian J. Res. Pharm. Sci, 3(3), 137-140. 
Kristiani, E.B.E., Kasmiyati, S., \& Herawati, M.M. (2015). Skrining fitokimia dan aktivitas antibakteri in vitro ekstrak heksana-petroleum eter Artemisia cina Berg.ex Poljakov. AGRIC, 27 (1), 30-37.

Mariita, R.M., Ogol, CKPO, Oguge, N.O., \& Okemo, PO (2011). Methanol extract of three medicinal plants from Samburu in Northern Kenya show significant antimycobacterial, antibacterial and antifungal properties. Res. J. Med. Plant, 5, 54-64.

Massiha, A., Khoshkholgh-Pahlaviani, M.M., Issazadeh, K., Bidarigh, S., \& Zarrabi, S. (2013). Antibacterial activity of essential oils and plant extracts of Artemisia (Artemisia annиа L.) in vitro. Zahedan Journal of Research in Medical Sciences, 15(6), 14-18.

Militello, M., Settani, L., Aleo, A. Mammina, C., Moschetti, G., Giammanco, G.M., Amparo, B.M., \& Carrubba, A. (2011). Chemical composition and antibacterial potential of Artemisia arborescens $\mathrm{L}$. essential oil. Curr. Microbiol, 62, 1274-1281.

Msaada, K., Salem, N., Bachrouch, O., Bousselmi, S., Tammar, S., Alfaify, A., Al Sane K., Ammar, W.B., Azeiz, S., Brahim, A.H., Hammami. M., Selmi, S., Limam, F., \& Marzouk, B. (2015). Chemical composition and antioxidant and antimicrobial activities of wormwood (Artemisia absinthium L.) essential oils and phenolics. Journal of Chemistry, ID 804658 12p.

Mohamed, A.E.H., El-Sayed, M.A., Hegazy, M.E., Helaly, A.E., Esmail, A.M., \& Mohamed, N.S. (2010). Chemical constituents and biological activities of Artemisia herba-alba. Rec. Nat. Prod, $4,1-25$.

Munyendo, W.L.L., Orwa, J.A., Rukunga, G.M., \& Bii, C.C. (2011). Bacteriostatic and bactericidal activities of Aspilia mossambicensis, Ocimum gratissimum, and Toddalia asiatica extracts on selected pathogenic bacteria. Res. J. Med. Plant, 5, 717-727.

Othman, L., Sleiman, A., \& Abdel-Massih, R.M. (2019). Antimicrobial activity of polyphenols and alkaloids in Middle Eastern plants. Frontiers in Microbiology, 911, 1-29.

Panche, A.N., Diwan, A.D., \& Chandra, S.R. (2016). Flavonoids: an overview. Journal of Nutritional Science, 5(47), 1-15.

Poiata, A., Tuchilus, C., Ivanescu, B., Ionescu, A., \& Lazar, M.I. (2009). Antibacterial activity of some Artemisia species extract. Rev. Med. Chir. Soc. Med. Nat. Iasi, 113, 911-914.

Prastiyanto, M.E., Wardoyo, F.A., Wilson, W., \& Darmawati, S. (2020). Antibacterial activity of various extracts of Averrhoa bilimbi against multidrug resistant bacteria. Biosaintifika: Journal of Biology \& Biology Education, 12 (2), 163-168.
Selim, S., El Alfy, S., Al-Ruwaili, M., Abdo, A., \& Al Jaouni, S. (2012). Susceptibility of imipenemresistant Pseudomonas aeruginosa to flavonoid glycosides of date palm (Phoenix dactylifera L.) Tamar growing in Al Madinah, Saudi Arabia. Afr. J. Biotechnol, 11, 416-422.

Sutton, S. (2011). Measurement of microbial cells by optical density. J. Valid. Technol, 17, 46-49.

Shin, J., Prabhakaran, VS \& Kim, K.S. (2018). The multi-faceted potential of plant-derived metabolites as antimicrobial agents against multidrug-resistant pathogens. Microb. Pathog, 116, 209-214.

Sibi, G., Chatly, P., Adhikari, S., \& Ravikumar, K.R. (2012). Phytoconstituents and their influence on antimicrobial properties of Morinda citrifolia. Res. J. Med. Plant, 6, 441-8.

Tajehmiri, A., Issapour, F., Moslem, M.N., Lakeh, M.T., \& Kolavani, M.H. (2014). In vitro antimicrobial activity of Artemisia аппиа leaf extracts against pathogenic Bacteria. Advanced Studies in Biology, 6 (3), 93 - 97.

Taleghani, A., Emami, S.A., \& Tayarani-Najaran, Z. (2020). Artemisia: a promising plant for the treatment of cancer. Bioorganic \& Medicinal Chemistry, 28(1), 115180.

Tan, R. X., Zheng, W. F., \& Tang, H. Q. (1998). Biological active substance from genus Artemisia. Planta Med, 64(4), 295-302.

Tokusoglu, O., Unal, M.K., \& Yildirim, Z. (2003). HPLC-UV and GC-MS characterization of the flavonol aglycons quercetin, kaempferol, and myricetin in tomato pastes and other tomato-based products. Acta Chromatographica, 13, 196-207.

Wahyuni, W.T., Purwanti, S., \& Batubara, I. (2018). Antibacterial and antibiofilm activity of Daemonorops draco resin. Biosaintifika: Journal of Biology \& Biology Education, 10(1), 138-144.

Xie, Y., Yang, W., Tang, F., Chen, X., \& Ren, L. (2015). Antibacterial activities of flavonoids: structure-activity relationship and mechanism. Current Medicinal Chemistry, 22, 132-149.

Younsi, F., Trimech, R., Boulila, A., Ezzine, O., Dhahri, S., Boussaid, M., \& Messaoud, C. (2016). Essential oil and phenolic compounds of Artemisia herba-alba (Asso.): composition, antioxidant, antiacetylcholinesterase, and antibacterial activities. International Journal of Food Properties, 19, 1425-1438.

Yemata, G., Desta, B., \& Fetene, M. (2019). In vitro antibacterial activity of traditionally used medicinal plants against Xanthomonas campestris pv. musacearum in Ethiopia. Biodiversitas, 20, $555-561$ 